\title{
Chinese Investments in Serbia-A Joint Pledge for the Future of the New Silk Road
}

\author{
Duško Dimitrijević \\ Institute of International Politics and Economics \\ Makedonska 25, \\ Belgrade 11000, Serbia \\ E-mail: dimitrijevicd@diplomacy.bg.ac.rs
}

Abstract: Following the political changes in 2000, Serbia has rapidly started to catch up with the countries of Central and Eastern Europe in various aspects of the transition process. One of these very important aspects were foreign investments, both 'direct' and 'portfolio' ones, that had a significant impact on the development of Serbian economy by recovering economic structure and raising competitiveness in world markets, followed by improving the balance of payments and technological, scientific and managerial base. Foreign investments as an "economic engine" enable accelerated realization of national economic goals which include re-industrialization and renewal of industrial capacity. The openness of the Serbian market and the lack of financial resources allow China and other states concerned under favourable conditions invest in the development of Serbian economy. In this way, Chinese investments have become a driving force for the promotion of economic and other relations between the two countries. On the other hand, however, Chinese investments have proven to be an ideal test for the realization of the objectives of the development strategy of the 'New Silk Road' which among other things include the improvement of China's position on world markets, including the EU market. For the proper understanding of Sino-Serbian relations, this study first gives a short explanation of the Chinese strategy of the New Silk Road. Then, it includes an analysis of Serbia's position towards China. Analysis of the development of Serbian-Chinese economic relations, especially in the field of foreign investment and within the framework of multilateral cooperation mechanism ' $16+1$ ', occupies the central part of the study. The study concludes with an 
evaluation of comparative advantages and certain disadvantages for the Chinese foreign investment in Serbian economy, which in itself has certain significance for the realization of the New Silk Road strategy.

Keywords: 16+1 mechanism, China, development strategy of the New Silk Road, foreign investments, Serbia, the Belt and Road initiatives

\section{Introduction to China's New Silk Road development strategy}

China's tremendous economic development has made the country an increasingly attractive economic partner in the first and second decade of the 21 st century. During this period, the ancient Silk Road trade route became attractive once again. Its symbolism in different geopolitical circumstances served China as the ideological basis for the proliferation of ideas of the New Silk Road, which has become, within the political paradigm of the "Chinese dream", the leading national development strategy. Building on the earlier proclaimed policy of the 'Peaceful Development', this strategy conceptually shaped China's efforts to consolidate the regional security and to ensure harmonious economic development of most of the world. This strategic concept of Chinese foreign policy came up together with the economic concept of 'Open door' which was applied in China for more than three decades and led to market-oriented reforms and gradual process of liberalization, from which were removed internal barriers in terms of movement of goods, labour and capital (Hongyuan, Yun \& Qifa, 2012, pp. 128ff). From 2000 onwards, China has made significant progress in the global market. Joining the World Trade Organization and strengthening its economic capacity, China has managed to occupy one of the leading positions in the world economy. Unfortunately today, like other global powers, China is facing serious economic threats caused by the world economic crisis and internal social tensions. These problems put aside exports and foreign direct investment as a leading Chinese economic development model. Given the difficult business conditions, China tries to find new export markets or preserve the existing ones. This is the main reason why the New Silk Road has developed in two political framework initiatives expressed through the phrases the Silk Road Economic Belt and the 21st-Century Maritime Silk Road, which China is usually referred to as Yi Dai Yi Lu (One Belt, One Road). 
The Silk Road Economic Belt initiative, announced by Chinese President Xi Jinping in September 2013, aims to promote cooperation between China and countries in Asia and Europe according to the new model, which should include:

1) Strengthening policy communication, which may help 'switch on a green light' for joint economic cooperation;

2) Strengthening road connections, with the idea to establish a great transport corridor from the Pacific to the Baltic Sea, and from Central Asia to the Indian Ocean, then gradually build a network of transport connections between eastern, western and southern Asia;

3) Strengthening trade facilitation, with a focus on eliminating trade barriers and taking steps to reduce trade and investment expenses;

4) Strengthening monetary cooperation, with special attention to currency settlements that could decrease transaction costs and lessen financial risk while increasing economic competitiveness;

5) Strengthening people-to-people relations. (Xinhua, 2013)1

On the other hand, the second initiative of the 21st-Century Maritime Silk Road, which was first mentioned by Chinese President Xi in early October 2013, should serve for improvement of maritime economy as well as environment protection, science, technology and security cooperation along the sea routes

Professor Liu Zuokui from the Institute for European Studies of the Chinese Academy of Social Sciences points out that "[t]he Silk Road Economic Belt has three routes on the corridor which refers to the Siberian Continental Bridge (also known as the First Eurasian Continental Bridge), starts from Vladivostok in the eastern part of Russia and ends in Rotterdam in the Netherlands; the New Eurasian Continental Bridge (also known as the Second Eurasian Continental Bridge), begins in Lianyungang in East China's Jiangsu Province and ends in Rotterdam. It exits China via the Alataw Pass and runs through Central Asia into Russia, Poland, and Germany; the third is the Eurasian Continental Bridge that is now on the drawing board. This proposed route would start from Shenzhen in Guangdong Province and end in Europe via Myanmar, Bangladesh, India, Pakistan, Iran, Turkey and Bulgaria." (Liu, 2015, p. 186) 
of southern Eurasia, from the Pacific coast to East Africa, the eastern Atlantic shores and Mediterranean. ${ }^{2}$

The Belt and Road initiatives have been proposed with the purpose of benefiting both China and the countries along the land and maritime route. They are open to all countries and international organizations (for example, Shanghai Cooperation Organization, the Eurasian Economic Community, Asia-Pacific Economic Cooperation, Asia-Europe Meeting, ASEAN plus China, BRICS, etc.), while adhering to the principles of mutual respect and common interests. The most important common economic interests include the improvement of trade and investment flows (facilitated through greater use of local currencies in cross-border exchange, and through currency swap arrangements between the People's Bank of China and other central or national banks), the improvement of transport infrastructure (the railway and highway network, and the deep water port facilities) and deepening economic integration (greater access to Chinese market for all countries along the route, and vice versa) (Dimitrijević \& Jokanović, 2016a, pp. 26-27; Xinhua, 2015a). In order to achieve these initiatives, China and the states concerned from different continents have established the Asian Infrastructure Investment Bank (AIIB) with an initial capital of 100 billion US dollars earmarked for funding infrastructure projects and promoting regional interconnectivity and integration (Xinhua, 2015b).

In line with the published Chinese projections, both of these initiatives are expected to become fully operational by 2025 (Escobar, 2015). These initiatives should boost the revitalization of the large part of the world which covers the vast area with more than 4.4 billion people. It is expected that the total value of these initiatives surpass 21 trillion US dollars (almost one third of the world's GDP) (Janković, 2016, p. 6). The network of investments that includes the Belt and Road initiatives might create the landmark infrastructure projects of the 21 st century (World Land-Bridge), encompassing 60 or more countries from different continents (Zepp-LaRouche, 2015, pp. 2ff). The importance of the Belt and Road initiatives is therefore huge, taking into account the number of countries they could encompass and the potential economic benefits for all of them. Hence, the Belt and Road initiatives

2 According to the recent information published by the Xinhua agency, the Maritime Silk Road begins in Quanzhou (Fujian) and hits other southern Chinese ports (Fujian, Zhejiang and Guangdong) before heading to the Malacca Strait. From Kuala Lumpur, the Maritime Silk Road heads to Kolkata, crosses the rest of the Indian Ocean to Nairobi and then around the Horn of Africa into the Mediterranean-with final stops in Greece and Italy. 
indicate a positive climate for building a new economic international system that could bring prosperity for a large number of countries that are on the New Silk Road, including Serbia, which, according to its specific position in international relations has a special significance for their implementation. ${ }^{3}$ In the following parts of the study, the author will try to present concrete facts concerning these allegations.

\section{Serbia's positioning towards the People's Republic of China}

Relations between Serbia and China follow the continuity of relations between Yugoslavia and the People's Republic of China that commenced with Yugoslav recognition of China on 1 October 1949. Since the two countries encourage friendly relations with each other and actively participate in the development through various forms of bilateral and multilateral cooperation at the regional, subregional and global level, it can be said that these relations become of prime and strategic importance. China is a very good economic partner of Serbia in Asia and one of the major pillars of Serbia's foreign policy. ${ }^{4}$ On the other hand, Serbia is one of China's key partners in the region of Southern and Eastern Europe. China primarily sees the Southern and Eastern Europe in terms of economic integration with the European Union as a common market of high purchasing power and

3 It seems very interesting to note that China came out with a list of priorities within the Belt and Road initiatives in February 2015. These priorities include building transporting infrastructure, facilitating the flow of investment and trade, simplification of customs procedures, the construction of logistics centres, financial cooperation, with the expansion of cooperation between nations through intensifying exchanges in culture, education, science, etc. In March 2015, the National Development and Reform Commission announced an important strategic document titled 'Vision and Actions on Jointly Building Silk Road Economic Belt and 21st-Century Maritime Silk Road'. This document outlines the framework of cooperation within the Belt and Road initiatives (NDRC, 2015a). On 22 October 2015, the same Commission adopted the Action Plan for Harmonization of Standards along the Belt and Road (2015-2017), which confirmed that the objectives of the previous adopted document ('Vision and Actions...'), will be achieved in practice (NDRC, 2015b).

4 In actual Serbian foreign policy strategy, China occupies an important place. The strategy is designed on four pillars of foreign policy. The first pillar is the European Union whose member Serbia would like to become. The second pillar is Russia as a rising power in world politics and Serbia's historical partner. The third pillar is the United States, as a great power with whom Serbia has had fluctuating relations in the past, but whose importance and influence in international relations Serbia has accepted as a reality. The fourth important pillar of Serbia's foreign policy strategy is China as a global economic power and the traditionally good friend of Serbia in international relations. (Dimitrijević \& Jokanović, 2016b, p. 328) 
therefore an ideal space for the placement of its own products. In this regard, it is important to note that China supports Serbia's aspirations for full accession to the European Union, without prejudice to its vital national interests. At this point it is worth mentioning that Serbia is granted the candidate status for membership in the European Union on 1 March 2012. In these circumstances, Serbia has taken a significant step towards the European common market, what in prospects can create an opportunity for achieving real economic growth and social development. In Serbia's economic and social transformation, China could also play a decisive role, because it does not pursue geostrategic redesigning of the European area but seeks maintaining the stability of the existing order. This is best seen through the role of China in the UN Security Council, where it is committed to the preservation of the territorial integrity of Serbia, not accepting a violent change of borders and unilateral proclamation of independence of Kosovo and Metohija. On the other hand, Serbia supports the territorial integrity of China, its sovereignty and right to regulate its relations with the former separate parts of its territory (One China Policy). Cooperation between the two countries is now at the highest level since the establishment of diplomatic relations in 1955, and each day is expanded with new positive content.

Given the described position of Serbia in relation to China, it is clear that the role of Serbia in the Belt and Road initiatives are determined by many factors. As is well known, Sino-Serbian relations are characterized by the strategic partnership established in August 2009 with a joint statement of the then presidents Boris Tadić and Hu Jintao. This strategic partnership was deepened in August 2013 with the joint statement signed by the presidents Tomislav Nikolić and Xi Jinping. In view of the fact, a series of framework agreements on political and economic cooperation have been concluded. For example, the Agreement on Economic and Technical Cooperation in the field of infrastructure signed in August 2009, paved the way for many other joint projects in the field of energy sector, transportation, agriculture, telecommunications, finance and cultural exchange. The importance of these projects and their profitability can only be understood in the context of the implementation of the Chinese development strategy of the New Silk Road, which includes objectives of the previously formulated Go Global strategy, with which China has encouraged its companies to exploit the world markets. Also, only in this context it would be possible to understand why China promotes its own economic growth through northern and southern trade routes that meet the Chinese demand for better regional cooperation, trade diversifications, investing in transportation, and in mining and energy sectors (Petrović-Piroćanac, 2014, pp. 86-98). Hence, Serbia's position towards China's development strategy of the New Silk Road depends on the 
understanding of global processes in the world and geo-economic interests of China that are channelled through the $16+1$ mechanism, which represents a political platform for cooperation between China and the countries of Central and Eastern Europe (CEEC). ${ }^{5}$ This cooperation mechanism should be in the function of the objectives of the Belt and Road initiatives (Long, 2015; China Daily, 2014). In relation to Serbia, this mechanism can also serve as a catalyst for the establishment of strategic cooperation with China in various productive spheres (Dimitrijević \& Jokanović, 2016b, p. 325). In this regard, for the purposes of this study, the author will focus on the effects of the Serbian-Chinese economic relations in the last decade.

\section{Economic relations between Serbia and China}

Economic relations between Serbia and China in the last decade have been characterized by mutual asymmetry in all economic parameters. The main cause of this situation is a huge difference in economic power, and then the Chinese global economic strategy that emphasizes the constant expansion of exports of domestic products and imports of energy and mineral resources for sustaining economic growth, with financial support from the state and state banks to those companies that operate in abroad. Hence, the economic cooperation between Serbia and China, in its scope, value and structure, unfortunately, has been a small part of the economic exchanges with the world of both countries (Babić, 2016, pp. 62-63).

According to the data of the National Bank of Serbia, in the period from 2005 to 2013, the total net monetary inflows from China amounted to 20 million euros (National Bank of Serbia, 2015). According to the official data of the Serbian Statistical Office, in the total commodity exchange, China was in the fifth place (after Italy, Germany, Russia and Bosnia and Herzegovina), while in terms of imports, China occupied the fourth place (after Italy, Germany and Russia). Serbia's exports to China in 2014 amounted to 14.1 million dollars, while in 2015 they amounted to 20.2 million dollars (accounting for only $0.1 \%$ and $0.2 \%$ of the total Serbian export). On the other hand, Serbia has imported

5 The 16 countries of Central and Eastern Europe, which are involved in the Chinese initiatives represent a heterogeneous group. There are 11 EU members (Bulgaria, Croatia, the Czech Republic, Estonia, Hungary, Latvia, Lithuania, Poland, Romania, Slovakia, Slovenia) and 5 countries from the western Balkans region which are potential candidates for EU membership (Albania, Bosnia and Herzegovina, Macedonia, Montenegro, and Serbia). 
goods from China in 2014 in the amount of 1,561 million dollars, while in 2015 , it imported goods worth of 1,540.2 million dollars (accounting for 7.6\% and $8.5 \%$ of the total import of Serbia in those years) (Serbian Statistical Office, 2015). According to official indicators of the Serbian Chamber of Commerce, in the first four months of 2016, there was an increase of bilateral trade by $2.9 \%$ compared to the same period last year. Exports recorded an increase of $22 \%$, while imports grew by $2.7 \%$. From January to November 2016, the value of imports from China in Serbia amounts to circa 1,480 million dollars (Chamber of Commerce and Industry of Serbia, 2016). Despite this asymmetry arising from real economic dominance of China, the two countries have a clear will to improve their economic and trade relations. This is best reflected through the Chinese investments in Serbia's transport infrastructure, energy and ICT sectors.

In this sense, in 2010 China and Serbia concluded an agreement on the construction of the bridge over the Danube River in Belgrade. The bridge on the Danube River was built by the Chinese state company China Road and Bridge Corporation (CRBC), a subsidiary company of China Communications Construction Company (CCCC). The bridge has a total length of 1,507 meters. With access roads the length is $21.6 \mathrm{~km}$. It was originally planned that the value of the project amounts to 260 million dollars. However, during the construction of the bridge that amount was exceeded (in September 2014 annex to the agreement was signed, with a predicted increase in the value of the project to an additional 70 million dollars for expropriation and 32 million dollars for compensation of contractors and subcontractors). The project is financed from the loan of Chinese Exim Bank (85\%) and from the funds of Serbia and the City of Belgrade (15\%). The bridge which was named after the great Serbian scientist Mihajlo Pupin, meanwhile, was built and opened in the presence of the highest state officials of both countries in December 2014 during the China-CEEC 16+1 Summit, in Belgrade. This investment project follows the plan of building a port on the Danube upstream from the Mihajlo Pupin bridge and a road-railway bridge over the Danube at Vinča.

A particularly significant investment in transport infrastructure is the construction of High-Speed Railway (HSR) from Belgrade to Budapest which should be operationalized by the abovementioned state-owned company China Communications Construction Company (CCCC) in consortium with the China Railway International company. The total length of the railways is $350 \mathrm{~km}$, of which the length on the Serbian side is $184 \mathrm{~km}$ and on the Hungarian side $-166 \mathrm{~km}$. In addition to the existing track, the plan envisages the construction of another, mixed type one for passenger and cargo transport. 
The project was first endorsed in November 2013 in Bucharest, following the meeting of prime ministers of Serbia, China and Hungary (Ivica Dačić, Li Keqiang and Victor Orban) on the sidelines of the China-CEEC Summit. A year later, in December 2014, a memorandum of understanding (MoU) on cooperation in the project of the Hungarian-Serbian railway was signed by Serbia, Hungary and China, on the sidelines of the third China-CEEC Summit in Belgrade in the presence of prime ministers of Serbia Aleksandar Vučić, of China Li Keqiang, of Hungary Victor Orban and of Macedonia Nicola Gruevski. On this occasion, the Framework Agreement on Joint Cooperation in Facilitating the Customs Cooperation between Serbia, China, Hungary and Macedonia was also signed, and the four parties undertook to intensify customs cooperation and to simplify customs procedures. The prime ministers of the four countries unanimously agreed to jointly work on building the Land-Sea Express Passage linking China and Europe (Zeldin, 2015). All this should lead to setting up a unified rail transport and customs system that would connect the port of Piraeus, through Macedonia with Serbia and Hungary and the rest of Europe, transporting goods from China to Central Europe and vice versa. Premier Li Keqiang said at the time that the "railway project will contribute not only to developing and connecting countries in the region, but also to further strengthening cooperation between China and the European Union" (Xinhua, 2014). ${ }^{6}$ On 24 November 2015, when Prime Minister Aleksandar Vučić attended the fourth Summit of China and 16 countries of Central and Eastern Europe in Suzhou, the Framework Agreement on the project was definitely signed. The project should be financed by China's Exim Bank. However, the pace of project implementation has slowed down due to the evaluation of the project (from Belgrade to Budapest) and then because of certain conditionality of the European Union in relation to the railway construction project through Hungary. Preliminary estimates released to the public say that the value of the project could be amounted from 1.5 to circa 2.5 billion euros. The total value of shares through Serbia was estimated to circa 400 million euros. ${ }^{7}$ After

6 Li Keqiang also stated that "China's cooperation with the 16 CEECs will not result in fragmenting the European Union," and that "China-CEEC cooperation is undoubtedly part and parcel of China-Europe cooperation". Li also expressed his hope that "the 16+1 grouping's development goals will be aligned with the China-EU 2020 Strategic Agenda for Cooperation" (Pavlićević, 2014, EurActiv, 2014).

7 In the previous period, the Serbian government has been actively working on keeping the cost of the Serbian section of Belgrade-Budapest railway down, even below 400 million euros. This represents a significant reduction from the originally announced budget of over 850 million euros. Instead of making a new loan arrangement with China, Serbia is interested in financing the project through its own budgetary means or with the help of a previously agreed loan with Russia (Pavlićević, 2015a). 
the trilateral meeting of the representatives of China, Hungary and Serbia, held in Belgrade in the first half of September 2016, the parties agreed that the signing of a commercial contract on the project of modernization and reconstruction of the Belgrade-Budapest railway should be performed at the Fifth Summit of the 16+1 mechanism in Riga, in November 2016. Finally, at the Fifth Summit in Riga, the Serbian company Serbian Railways together with the Representative of the Government of Serbia, signed a commercial contract for the construction of the first section of speed railway BelgradeBudapest (of the length of $34.5 \mathrm{~km}$ from Belgrade to Stara Pazova) with a consortium of Chinese companies - China Railway International and China Communications Construction Company - in the amount of circa 319 million euros. Serbia has signed a memorandum of understanding with China's Exim Bank which envisages lending to the construction of that section of high-speed railway through Serbia. (Politika, 2016, p. 5)

On the basis of the data presented, it is essential to understand that the construction of the Belgrade-Budapest railway is part of China's development strategy of the New Silk Road, which aims to connect the port of Piraeus with the Central and Western Europe through Macedonia, Serbia and Hungary. The railway project will serve as an important impetus for the economic development of Serbia, Hungary and other countries in the region. The importance of this project for Serbia is also echoed by Prime Minister Aleksandar Vučić's remarks that "the Belgrade-Budapest railway would contribute to the realization of the transport networks, as well as to the movement of people and goods, which would hitherto encourage the creation of logistics routes and distribution centres, and long-term access to new markets."

At the Fourth China-CEEC Summit in Suzhou, in November 2015, Serbia became a leader among CEECs in implementing joint infrastructure and energy projects with China. In Suzhou, China and CEECs supported Serbia's efforts to establish a China-CEEC centre for transport infrastructure and cooperation in Belgrade (Tianping, 2015). Bearing in mind Serbia's geographical location, traffic and energy connections with the region and beyond, the heads of government of China and CEECs concluded that

\footnotetext{
Interestingly, Serbia and the countries in the region have not given up on the project Morava, which is also considered a possible direction in the framework of implementation of the strategy of the New Silk Road. Namely, on the basis of the protocol signed in January 2013, China Gezhouba Group Corporation (CGGC), has prepared a feasibility study for the construction of part of the channel Danube-Morava-Vardar through Serbia. The study included the project Channel Morava, whose value is estimated at 4.5 billion euros. As a potential contractor in 2016, the Chinese company Bonn Project is mentioned.
} 
Serbia could be an important link along the Silk Road. Therefore, the parties gave support for the construction of industrial parks along the Danube. In addition, in the field of Serbian transport infrastructure, China also supported investment in two sections of Corridor 11 (highway E-763 Belgrade-South Adriatic): Obrenovac-Ub and Lajkovac-Ljig, in total length of $50.23 \mathrm{~km}$. The construction of this highway section was taken over by the China Shandong International Economic \& Technical Cooperation Group (CSI). Currently, the Chinese company is working on the construction of the remaining part of the road, with completion due by the end of July 2017. The total value of the project is 337.74 million dollars. The project is financed from the loan of China's Exim Bank (in the amount of 301 million dollars) and from the budget of Serbia (32.74 million dollars). The construction of the highway section from Surčin to Obrenovac on the section of Corridor 11 (E763), a total length of $17.6 \mathrm{~km}$, including the bridge over the Sava River was taken over by the China Communication Construction Company (CCCC). According to the construction plan, the works should start in 2017. The value of the project amounts to 233.69 million dollars. The participation of the Chinese side in the project is $51 \%$, and of Serbian companies- $49 \%$. The project will be financed from the loan of China's Exim Bank.

The Chinese state company Sinohydro Corporation signed with the Serbian side a memorandum of understanding which envisages participation in the construction of the bypass around Belgrade, in consortium with the Azerbaijani company AZVIRT. Implementation of the project foresees banded straight lines which connect Serbia with Hungary, Croatia, Montenegro and Macedonia. The bypass should be the total of $46 \mathrm{~km}$ in length. The contract for the financing of the project is not yet completed.

At the Third Summit between China and the CEEC, held in Belgrade, China and Serbia signed an agreement on the establishment of air traffic between the two countries. The agreement provides flights between Belgrade, Beijing and Shanghai. As envisaged, investing in air transport should be carried out by the companies Air Serbia and Air China. ${ }^{9}$

All the above mentioned investments follow China's investments in Serbia's energy sector. The first investment relates to the revitalization of the Kostolac B Power Plant with a value of million dollars. This project is funded by China on the basis of state-to-state loan under preferential conditions. It is important

9 In March 2016, also the Aviation Industry Corporation of China (AVIC) has expressed interest in investing in the Belgrade Nikola Tesla Airport and smaller airports in Serbia. 
to note that China's Exim Bank had approved Serbia's new loan of 608.26 million dollars to build a new thermal block Kostolac B3 of 350 MW and expand the pit mine Drmno from 9 million tons to 12 million tons per year (Pavlićević, 2015b, p. 11). The loan was approved with repayment period of 20 years, a grace period of 7 years. The total value of the second phase of the revitalization of the Kostolac Power Plant is 715.6 million euros. Additional funding, if necessary, will be provided to Serbia and its public company Electric Power Industry of Serbia (EPS). The new thermal bloc will be built in 58 months and it is expected that the work will be completed by the end of 2019. The revitalization and construction of the Kostolac thermal power plant was taken over by the China National Machinery and Equipment Import \& Export Corporation (CMEC).

In addition to these investments, Chinese companies China Environmental Energy Holdings (CEE) and the Shenzhen Energy Group (SEC), in consortium with the Serbian public company Electric Power Industry of Serbia (EPS) participate in the construction of Block 3 of the Nikola Tesla B Thermal Power Plant in Obrenovac and the pit mine Radljevo. The projected installed capacity of the new unit is $744 \mathrm{MW}$. The total project cost is estimated at over 2 billion euros. According to information issued for the public, the new power plant is expected to become an independent producer of electric power, a majority Chinese-owned venture. The dynamics of the implementation of the project is uncertain due to the floods that hit Obrenovac and its surroundings in 2014.

In the field of renewable energy, it is important to note that Serbia and China have made sufficient progress. Thus, in July 2016, the Silk Road Fund, China Gezhouba Group (CGGC) and China Environmental Energy Holdings signed with the Serbian side a memorandum of understanding and joint investment in renewable energy projects in Serbia. Also, the Chinese company Goldwin undertook an obligation to supply Serbia with wind turbines, while China Machinery Engineering Company signed a memorandum of understanding which provides financing and construction of a power plant that will generate electricity from waste.

In addition to these investments, China has invested in Serbian ICT sector. These investments contribute to accelerated economic and technological development of Serbia and are very important for Serbia's inclusion in the modern economy. An illustrative example is the investment in Serbianintegrated telecommunications system for which the Chinese company Huawei Technologies and Serbian Railways company have signed a memorandum of 
understanding in 2011. This MoU was followed by agreements on technological cooperation in 2012, and in 2013. The estimated value of the project amounts to circa 200 million euros. The first phase of modernization should be completed by 2018 , and the total value of the works is estimated at 78 million euros. The planned sections of railway lines were Corridors 10 and 11, Pančevo-Vršac and Požega-Kraljevo-Lapovo. Another significant example is investment in the Serbian company Telekom, agreed in July 2016. The agreement that was signed with Huawei Technologies provides the procurement of equipment and materials, construction and provision of services for the implementation of the ALL IP transformation. The investment is based on a preferential loan from a Chinese bank, amounting to 150 million euros.

Strategically, China's probably the most important investment in Serbia is investment in the Serbian company Iron Works Ltd. in Smederevo. This investment speaks in favour of the overall growth of Chinese industrial investments in Serbia (Yang \& Zhang, 2016). The importance of this investment of 46 million euros is expressed through the reduction of the deficit of Serbian foreign trade balance with China, as well as the increase in GDP for 1\%. Also, this investment affects employment growth and living standards. The investment is including an additional investment of at least 300 million euros, increases industrial activity and capacity of the Serbian economy (Politika, 2016, p. 5). This way, further incentives for Chinese investments in Serbia would represent mutual benefit because they promote mutual economic cooperation, raise the level of political relations, and improve the cultural, scientific and technological exchange and cooperation, and thus create the preconditions for the realization of long-term development strategy of the New Silk Road as a pledge for a common future. 


\section{Concluding remarks regarding Chinese investments in Serbia}

Chinese investments in Serbia represent a huge opportunity for development as well as good evidence of the successful conduct of foreign policy of the two countries which promote economic cooperation not only at the interregional but also at the global level, contributing to the harmonization of relations between East and West. In this context, the mechanism of multilateral cooperation 16+1 represents a significant political tool with which it is possible to achieve the development of mutual cooperation between China and the countries of Central and Eastern Europe, as well as achieve a comprehensive strategic partnership between China and the European Union. ${ }^{10}$ As an active participant in the $16+1$ cooperation mechanism, Serbia could also be a good partner in realization of the Chinese development strategy of the New Silk Road. First, because the relations between the two countries are imbued with mutual understanding and trust, and second, China and Serbia are sufficiently open to promote various forms of economic cooperation (Janković, 2016, p. 16). This is best reflected in the presence of Chinese investments in Serbia that contribute to improving industrial capacity and living standards. However, in this regard, there are certain doubts because the participation of Chinese investments in the Serbian economy have remained modest (Jackoby, 2015). Also, their importance for accelerated economic growth is limited to certain industries such as transport infrastructure, energy and ICT sectors. Although there is a tendency of growth and expansion in other industries, these investments are criticized for being exclusively based on state-to-state loans by providing state guarantees, which in the long run brings into question their feasibility and financial profitability (Pavličević, 2015a). Of course, there are some general weaknesses that are not related directly to Chinese investments since they

10 At the Fourth Meeting of CEEC and China, held on 24 November 2015 in Suzhou (China), the Prime Minister of China Li Keqiang said: "China supports the European integration process, as well as a united, stable and prosperous Europe that plays a greater role in the international community... China's cooperation with the 16 CEECs will not result in fragmenting the European Union. Much to the contrary, it will help deepen cooperation between China and the European Union and narrow the development gap between the eastern and western parts of the European Union... China-CEEC cooperation is undoubtedly part and parcel of China-Europe cooperation, and the two could naturally go in parallel and be mutually reinforcing." (Pavlićević, 2015b, p. 12). According to the joint statement made during President Xi's trip to the EU headquarters, China and the EU decided to develop synergies between China's Silk Road Economic Belt initiative and EU policies and jointly to explore common initiatives along these lines (Ministry of Foreign Affairs of the PRC, 2014). 
stem from the macroeconomic indicators of Serbian economy that prevent their greater financial efficiency (for example, inadequate economic structure, insufficient use of production capacities, outdated technology, inflexible labour market, limited domestic consumption, poor liquidity, lack of transparency of institutions and procedures, administrative barriers, corruption, etc.) (Petrović \& Mirković, 2011, p. 258).

In this respect, China's efficient and profitable investment activity in Serbia cannot stand any uncertainty. The basic precondition for China as a capital exporting country to be willing to invest in Serbia as a host country is security of its investments. In this regard, it is important that Serbia has adopted a new law on investments in 2015, which guarantees equal legal status of domestic and foreign investors. Regardless of the form of foreign investments (purchase of shares, stakes in already existing companies, establishment of a new company, concessions, B.O.T. arrangements, etc.), Serbian law guarantees freedom of investment, followed by the national treatment, legal certainty and the ability to transfer profits abroad. These guarantees for foreign investors were created during the multi-year business and financial reform legislation, which led to improving investment climate needed to attract foreign investments.

The analysis of the potential benefits of future Chinese investments in Serbia includes, in addition to the above questions, an examination of comparative advantages that Serbia has and that can contribute to improving the structure and volume of Chinese direct investment. A list of these indicators includes, among others, the following advantages: (1) a clear foreign policy goal-joining the EU and the World Trade Organization; (2) relative macroeconomic stability; (3) highly qualified and cheap labour; (4) regionally competitive financial risk; (5) restructured and privatized banking sector; (6) accelerated development of capital market; (7) contribution to the development of telecommunications infrastructure; (8) liberalized system of tariffs; (9) accelerated development of the private sector; (10) significant level of achieved stimulating fiscal, regulatory and financial measures; (11) adoption of a strategy for encouraging and developing Foreign Investment; (12) "more or less" harmonized legal framework for foreign investment with European and international standards; and (13) full visa liberalization. ${ }^{11}$ A significant proximity of European markets and the soon-expected improvement of the transport infrastructure can also represent a comparative advantage for future Chinese investments in Serbia, particularly in the field of agriculture (especially meat processing), car industry

11 Serbia is the only country in the CEE region that has this status on the basis of the agreement signed with China at the Fifth Summit in Riga (Xinhua, 2016). 
(in particular lorries and spare parts), telecommunication, machine, chemical and textile industries (Večernje Novosti, 2015; Blic, 2014).

\section{Conclusion}

From the abovementioned analysis which refers to the development of the economic relationship between Serbia and China, especially in the field of investments, we have come to the following conclusions.

First, the economic relations between Serbia and China in the last decade have been characterized by mutual asymmetry in all economic parameters. The main reason for this situation is a huge difference in economic strength, and China's global economic strategy which emphasizes the continuous expansion of Chinese exports and imports on the world markets. Second, the main determinant of Chinese foreign investments in Serbia in this respect follows the "less or more" identical model presented in other countries of Central and Eastern Europe. Chinese foreign investments, in practice, take place within the engagement of Chinese state-owned companies and state banks, with a less participation of local companies in investment operations. These investments are generally secured by state guarantees (or guarantees of the central banks of host states). This model thus evokes a certain suspicion especially in the case of countries with a strong balance of payments deficit and high external indebtedness. Third, if Serbia aspires to increase its influence and importance in international relations on the basis of economic cooperation with China, its business with China must be based on improving industrial capacity through various types of investments in different industrial areas, which could lead to overall economic growth (Pavlićević, 2015b). In this sense, Serbia should be included in international production by means of global value chains that are derived not only from the ownership forms of foreign investment, but also from non-equity investments (Kozomara, 2014, p. 109). Serbian companies, in this way, could participate proportionally in exports through global value chains whose holders are Chinese companies, which would in perspective lead to economic growth and development of economic relations. Given that macroeconomic imbalance in Serbia affects the dynamics and structure of investment inflows, especially greenfield investments, the branch structure of Serbian exports will tend to be transformed in accordance with the structure of accumulated foreign direct investments. Therefore, encouraging new Chinese greenfield investment (including takeovers and acquisitions) can contribute to 
the gradual re-industrialization of the Serbian real economy and thus, to the promotion of win-win cooperation, which, as a joint pledge, could lead to faster and more effective embodiments of the New Silk Road development strategy.

Duško Dimitrijević is professorial fellow at the Institute for International Politics and Economics (IMPP) in Belgrade, Serbia. From 2009 to 2014, as director of the IMPP, he established scientific cooperation with the Chinese Academy of Social Sciences, the Shanghai University and other eminent academic institutions from China. He has published dozens of scientific papers in scientific journals as well as outstanding monographs and thematic proceedings in international law and international relations. He is a member of the Serbian Lawyers' Association, the Serbian International Law Association, which is a chamber of the International Law Association in London. He is Editor-in-Chief of the scientific journal Evropsko zakonodavstvo ('European legislation').

\section{References}

Babić, B. (2016), "New Silk Road - China's New Deal," in D. Dimitrijević (ed.) Danube and the New Silk Road, Belgrade: Institute of International Politics and Economics.

Blic (2014), 'Kineski ZTE: Imamo agresivan poslovni plan za Srbiju' [Chinese ZTE: We have an aggressive business plan for Serbia]. Retrieved from http://www.blic.rs/ Vesti/Ekonomija/520251/Kineski-ZTE-Imamo-agresivan-poslovni-plan-za-Srbiju [accessed Sep 2015]

Chamber of Commerce and Industry of Serbia (2015), Economy of Serbia. Retrieved from http://www.pks.rs/PrivredaSrbije.aspx [accessed Feb 2016]

China Daily (2014), 'China calls on CEEC to join Silk Road project.' Retrieved from http://www.chinadaily.com.cn/china/2014-05/14/content_17507780.htm [accessed Jun 2014]

Dimitrijević, D. \& Jokanović, N. (2016a), "China’s New Silk Road Development Strategy," Review of International Affairs, vol. LXVII, no. 1161.

- (2016b), 'Chinese investments in Serbia and the New Silk Road,' in D. Dimitrijević (ed.) Danube and the New Silk Road, Belgrade: Institute of International Politics and Economics.

Escobar, P. (2015), "The 21st century belongs to China: Why the new Silk Road threatens to end America's economic dominance," Salon, 24 February 2015. Retrieved from http://www.salon.com/2015/02/24/the_21st_century_belongs_to_china_why_ the_new_silk_road_threatens_to_end_americas_economic_dominance_partner/ [accessed Feb 2015] 
EurActiv (2014), 'China Boosts Investment in Central and Eastern Europe.' Retrieved from http:/www.euractiv.com/sections/europes-east/china-boosts-investmentcentral-and-eastern-europe-310997 [accessed Jun 2014]

Hongyuan, L.; Yun, G. \& Qifa, S. (2012), China's Road, Beijing: Huangshan Publishing House.

Jackoby, W. (2015), 'Chinese Investment in the Balkans,' in Re-imagining the Silk Road, Special feature, Council for European Studies.

Janković, A. (2016), 'New Silk Road - New growth engine,' Review of International Affairs, vol. LXVII, no. 1161.

Kozomara, J. (2013), 'Serbia in international production through global value chain,' in P. Petrović (ed.) Possibilities and Perspectives for Foreign Direct Investments in the Republic of Serbia, Belgrade: Institute of International Politics and Economics.

Liu, Z. (2015), 'The Role of Central and Eastern Europe in the building of Silk Road Economic Belt,' International Problems, no. 2-3.

Long, J. (2015), 'Cooperation between China and CEE countries: features, significance and prospect,' Diplomacy Journal. Retrieved from http://diplomacy.bg/ archives/1438?lang=en [accessed May 2015]

Ministry of Foreign Affairs of the PRC (2014), Joint Statement Deepening the ChinaEU Comprehensive Strategic Partnership for Mutual Benefit, 31 March 2014. Retrieved from http://www.fmprc.gov.cn/mfa_eng/wjdt_665385/2649_665393/ t1145387.shtml [accessed Jun 2014]

National Bank of Serbia (2015), Statistics. Retrieved from http://www.nbs.rs/internet/ cirilica/index.html [accessed Feb 2016]

NDRC (2015a), 'Vision and Actions on Jointly Building Silk Road Economic Belt and 21st-Century Maritime Silk Road,' National Development and Reform Commission, Ministry of Foreign Affairs and Ministry of Commerce of the People's Republic of China. Retrieved from http://en.ndrc.gov.cn/newsrelease/201503/ t20150330_669367.html [accessed Jun 2016]

(2015b), 'Action Plan for Harmonisation of Standards Along the Belt and Road (2015-2017),' National Development and Reform Commission, Ministry of Foreign Affairs and Ministry of Commerce of the People's Republic of China. Retrieved from http://china-trade-research.hktdc.com/business-ews/article/OneBelt-One-Road/Action-Plan-for-Harmonisation-of-Standards-Along-the-Beltand-Road-2015-2017/obor/en/1/1X000000/1X0A443L.htm [accessed Jun 2016]

Pavlićević, D. (2014), 'China and Central and Eastern Europe: On the Fast Track,' China Policy Institute Analysis. Retrieved from https://blogs.nottingham.ac.uk/ chinapolicyinstitute/2014/12/19/china-and-central-and-eastern-europe-on-thefast-track/ [accessed Jun 2016]

(2015a), "China's New Silk Road Takes Shape in Central and Eastern Europe," China Brief, vol. XV, no. 1. 
- (2015b), 'Chinese Infrastructure Investments in Serbia: Between Politics and Profit,' Council for European Studies. Retrieved from http://councilforeuropeanstudies. $\mathrm{org} / \mathrm{critcom} / \mathrm{chinese}$-infrastructure-investments-in-serbia-between-politics-andprofit/ [accessed Jun 2016]

Petrović, P. \& Mirković, A. (2011), 'General characteristics of Foreign Direct Investment in Serbia,' in M. Antevski (ed.) Development Potentials of Foreign Direct Investment: International Experiences, Belgrade: Institute of International Politics and Economics.

Petrović-Piroćanac, Z. (2014), 'The World and a Chinese Non-alignment Strategy of Governance and Development-Brief Survey,' in Global Trends and China in the Coming Decade, Papers from 'Contemporary World Multilateral Dialogue 2013', China Centre for Contemporary World Studies, China Foundation for Peace and Development, China Energy Fund Committee.

Politika (2016), 'U Rigi potpisani ugovori vredni 734 miliona dolara' [Contracts worth 734 million dollars signed in Riga], 6 November 2016.

Serbian Statistical Office (2015), [Homepage]. Retrieved from http://webrzs.stat.gov.rs/ WebSite/ [accessed Jun 2016]

Tianping, K. (2015), '16+1 Cooperation framework: Genesis, Characteristics and Prospect,' International Problems, no. 2-3.

Večernje Novosti (2015), 'Kinezi ulažu u mesnu industriju' [The Chinese are investing in the meat industry]. Retrieved from http://www.novosti.rs/vesti/naslovna/ ekonomija/aktuelno.239.html:563532-Kinezi-ulazu-u-mesnu-industriju [accessed Sep 2015]

Xinhua (2013), “Central Committee's Decision on Major Issues Concerning Comprehensively Deepening Reforms," 15 November 2013.

_ (2014), 'China, CEE Countries Outline Blueprint for Further Economic Cooperation.' Retrieved from http://news.xinhuanet.com/world/2014-12/17/c_1113667695.htm [accessed Dec 2014]

(2015a), 'China Focus: China sketches out priorities of Belt and Road initiatives.' Retrieved from http://news.xinhuanet.com/english/china/201502/01/c_133962709.htm [accessed Mar 2015]

_ (2015b), "Chronology of China's 'Belt and Road' initiatives.” Retrieved from http://news.xinhuanet.com/english/china/2015-02/05/c_133972101.htm [accessed May 2015]

— (2016), 'Full text of Riga Declaration.' Retrieved from http://www.china-ceec.org/ eng/zyxw_4/t1414325.htm [accessed Nov 2016]

Yang, Z. \& Zhang, Y. (2016), “Experts welcome Hesteel's Serbian steel buy.” Retrieved from http://europe.chinadaily.com.cn/business/2016- 04/20/content_24685303. htm [accessed Jun 2016] 
Yordanov, Y. (2015), 'Chinese Foreign Policy and Economic Involvement in SouthEastern Europe,' in Re-imagining the Silk Road, Council for European Studies.

Zeldin, W. (2015), 'China: New Guidelines for Cooperation Signed with Central and Eastern European Countries.' Retrieved from http://www.loc.gov/lawweb/servlet/ lloc_news?disp3_1205404250_text [accessed May 2015]

Zepp-LaRouche, H. (2015), 'The New Silk Road Leads to the Future of Mankind!' in The New Silk Road Becomes the World Land-Bridge, Washington, DC: EIR News Service Inc. 